\title{
EXPRESSING PROFANITY IN CEBUANO AND BAHASA SUG
}

\author{
${ }^{1}$ Rodney C Jubilado, 2Sajed Ingilan \& ${ }^{2}$ Francisco Perlas Dumanig \\ ${ }^{1}$ University of Hawaii \\ ${ }^{2}$ University of Southeastern Philippines \\ ${ }^{3}$ Buraimi University College, Oman \\ (rodneycj@hawaii.edu)
}

\begin{abstract}
This ethnographic paper deals with the expression of profanity in Cebuano and Bahasa Sug. Data has shown that various profanities in these two languages are based on religion, sex, effluvia, and assault to the "face". Spanish and Arabic loanwords are manifested in Cebuano and Bahasa Sug, respectively, due to religion. Sex-based profanities, effluvia, and profanities against the "face" are expressed using the indigenous languages. It is noteworthy that Cebuano has more expressions of profanity compared to Bahasa Sug. For the Christian Cebuanos, uttering profanity is more of a pardonable venial $\sin$ in contrast to the unpardonable mortal sin. For the Muslim speakers of Bahasa Sug, Islam is a way of life which goes strongly with the observance of adat, the customary laws. Hence profanity among speakers of Bahasa Sug is sanctioned by the Islamic faith and declared haram, religiously forbidden.
\end{abstract}

Key words: profanity, blasphemy, sex, taboo, effluvia, Cebuano, Tausug, haram, adat

\section{Introduction}

Profanity, in its different manifestations, is always frowned at and is often labelled taboo in various societies. When profanity is equated with blasphemy, the direct connotation is that it is against anything holy or any deity that any member of society worships and the person who utters profanity is considered either secular, atheist, immoral, irreligious or downright evil. Where anything sacred is used in, acted upon, or become the target of profanity, such act can be construed as desecration and labelled as a crime against religion. It can be 
punishable by stringent laws in many "religious" societies (Roberts \& Yamane, 2012) such as in "political Islam" (Asad, Brown, Butler, \& Mahmood, 2013; Bibi \& Tollet, 2013) and in "Christianity" during the Spanish Inquisition and the Puritan movement (Murphy, 2013; Gildrie, 2004).

Aside from religion-based profanity, other forms of profanity deal with effluvia, which is the cover term for bodily secretions either in gaseous, liquid or solid forms. The level of profanity associated with various bodily secretions depends upon the society. Some words of bodily secretions are deemed more profane and elevated to the level of taboo (Holder, 2008). For Allan \& Burridge (2006:11), "Taboo refers to a proscription of behaviour for a specifiable community of one or more persons, at a specifiable time, in specifiable contexts."

Equally effective is the use of words associated with sex in profanity. From the purview of public morality, every conservative society can attest to the fact that uttering sexual terms in public are downright vulgar and detestable. So strong is the censorship that every time sexual profanity is uttered in a film, live telecast, TV programs, and other broadcast media, the predictable bleep sensor is activated and heard of replacing such utterance. Censorship is the natural and imposing reaction of the authority towards profanity in the broadcast media (Jenings, 2009; Silverman, 2007; Heins, 2001).

With words expressing profanity being taboo, social pressure makes members of the society resort to the use of euphemism due to censorship. Merriam-Webster Dictionary defines euphemism as "the substitution of an agreeable or inoffensive expression for one that may offend or suggest something unpleasant". Language, which functions for communication, has its lexical provisions to be used when conservative societies require it to lessen the gravity of offensiveness of profanity. As such euphemism is devised to circumvent the repressive nature of censorship and social pressure against profanity (Allan \& Burridge, 2006). Jay (2000:86) stated that "Euphemisms and circumlocutions are commonly used to talk about sex and taboo topics." Proscriptions of all types of vulgarities, profanities, taboos and other lexicalized improprieties in a given society are a huge part of regulating social behaviour to which politeness is one of the ultimate goals (Culpeper, 2011; Watts, 2003; Brown \& Levinson, 1987). It is noteworthy to mention that taboo is culture-specific and time-constrained. Therefore, what is considered taboo in some cultures may not be in the others, and what is considered taboo today may not be taboo tomorrow or in the yesteryears.

In this ethnographic paper, the working blanket definition of profanity includes cursing, swearing, and all terms and expressions considered taboo, 
vulgar, lewd, blasphemous, pejorative, sexual, among others, which are directly proscribed or prohibited by the society. Within the Philippine context, since the languages studied in this paper are Cebuano and Tausug, terms and expressions used against the "face" condescendingly and pejoratively are also included. By face, we mean the dignity, self-esteem, and self-worth of a person in particular and the community in general. The "face" holds too much importance which borders sanctity in the Philippine community. Assaulting the "face" is an injury not only to the person but also to his family. In closely knit clans in a community, offending a member means offending the entire family or the clan. An assault to the "face" is not easily forgiven or forgotten as those historical records of juramentado, rido, and pangayaw in the history and sociology of the Philippines could testify (Tan, 2009; Torres, 2007; Rodell, 2002; Majul, 1999; Jocano, 1998; Agoncillo, 1990). The Dictionary of Psychology (Corsini, 2002: 518) has this entry for juramentado: "A culture-specific syndrome seen in some Malays and Moros with animistic beliefs. Victims are suddenly overwhelmed by frenzy, rush about stabbing everyone they encounter, after which they lapse into a stuporous sleep from which they awaken with complete amnesia for the episode. The seizures are often preceded by exciting religious rites or by a devastating emotional experience such as the death of a loved one." Rido is a Maranao word which signifies an intermittent feud among Muslim clans in Mindanao. This term is tied to the concept of shame and the endangering of honour. Retaliatory and punitive acts often cause destruction to property, life, and community (Kreuzer, 2005; Torres, 2007). Pangayaw is the term, used by the non-Islamized indigenous people, corresponding to the rido among Muslims in Mindanao (Kamlian, 2005).

As such, by using ethnographic approach, what is aimed in this paper is the attempt to present an analysis on the profanity used by speakers of Cebuano and Bahasa Sug. The linguistic varieties of these languages are those spoken in Davao Region in the Philippines. Cebuano speakers, who are also called Cebuano, are professing Catholic Christians, while the Bahasa Sug speakers, called Tausug, are believers of Islam. This research delves into the influence of religion in the use of profanity among speakers of Cebuano and Bahasa Sug from the lexical, phraseological, and sentential levels to the conceptual structures associated with the expressions of profanity.

\section{Views on profanity among believers}

One of the characteristics of profanity is its direct antagonistic relationship with anything holy as embodied by religion. The fact that profanity is a secular 
expression of indifference towards religion is a cringing, glaring, and stark opposition to the sanctity of anything held sacred. However, this concept is about the commonly practised religion in a given place. This section presents views on profanity from the informants professing and observing the religions of Christianity and Islam. Along with Judaism, Christianity and Islam are often termed as Abrahamic religions, owing to the fact that these three religions traced their roots down to Abraham, "the founding father" and "ancestor par excellence" (Hendel, 2005:33).

\section{Views from Christians on profanity}

In Christianity, the Bible has many verses referring to profanity that has to be avoided as stated in Leviticus 19:12 and Matthew 5:32 of the American Standard Version. Profanity is considered a "venial sin", which is pardonable, as opposed to mortal sin, which sends a Christian soul to eternal damnation (Giesler, 2010:75). In the Catechism of Roman Catholic Church, sins are "evaluated according to gravity", and are categorised as "venial sin" or "mortal sin". The exact words quoted from the Catechism of the Catholic Church are quoted as follows: "Mortal sin destroys charity in the heart of man by a grave violation of God's law; it turns man away from God, who is his ultimate end and his beatitude, by preferring an inferior good to him. Venial sin allows the charity to subsist, even though it offends and wounds it." There is equal footing between "profanity and uncleanness" in the sense that profanity equates with the absence from the "divine sphere" as opposed to holiness which signifies "presence in the divine sphere" (Burnside, 2003: 123). For the informants who are professing Christianity, samples of their views on profanity are as follows:

"Profanity is not a good deed towards other people because you are treating them in an abusive way. I don't like profanity because it can degrade other people" -KG "Profanity is not good. I also don't like because it can hurt people around you." -RJP

"Profanity is something bad that is against human rights. I hate profanity because it is like treating other people like animals." - MJA

"When I hear the word profanity, I always think of the word "abusive". I don't like it because it is not good." - EJP

"Profanity is something against human rights. I don't like profanity because it is not good." - MTD 
"For me, profanity is an act wherein one person cases of abuse and oppresses another person. I am a person who is strongly against profanity because it is not good." - KEP

"For me, profanity is one of the things that should not have existed in our world. I hate profanity because people take advantage of the weak people." -JJC

"Profanity must not exist in our society because of the negative feedback. I don't like profanity because it harms people." - AU

"Profanity is one of the worst things that happen in this world. I am one of the persons who are against profanity because it harms people." - MALZ

The preceding samples of views on profanity among professed Christian informants are in one accord in describing that profanity is not good for it is "abusive" and an act of taking "advantage of the weak". One informant coded MT, strongly pointed out by saying, "Profanity is a hazard. It must be eliminated from the society."

\section{Views from Muslims on profanity}

In Islam, there are two verses in the English translation of the Quran by Abdullah Yusuf Ali that mention profanity directly, namely, Al Araf Chapter 7:180 and Al-Hajj Chapter 22:25, and requital and grievous penalty await those who commit profanity. Just like in Christianity, profanity manifested in the form of cursing, swearing, and blasphemy is also a sin in Islam (Muhammad Bin Uthman Adh-Sgagabu, 1993). Following are samples of views on profanity from informants who profess Islam.

"Profanity makes people angry and causes friction. It destroys a language of race or nation. When I hear profanity, I call the attention of the person who utters it. It destroys the image of the speakers that makes the particular language of that person also dirty." - MX1

"Profanity is not suitable to be used by anyone. It causes many things such as hurting someone's feelings, fighting, and may end the friendship. When I hear profanity, I feel sad and unappreciated. Besides, I feel so disappointed with the person who utters such profanity. It is rude, and it hurts people's feelings." - RABJ 
"It must somehow be stopped to avoid unwanted problems. It makes me unhappy because you are a bully through acts and words." - ARL

"I think profanity is an uncomfortable word, and when used in communication or conversation, it may cause unpleasantness, dissatisfaction, and offence. Anyone who uses profanity is someone who speaks with no qualms at all time. Their language shows that they are discourteous and impolite. Language reflects the characteristics of the person. When I hear profanity, it makes me angry. Profanity lowers self-esteem and makes someone feel uncomfortable. When someone speaks profanity to me, it shows that the person does not respect me." - NABR

"Profanity is treating someone in an abusive way which is an act of bullying that should be stopped. It is an act that could hurt people emotionally, and when they grow up, they will bully other people, too. - RIB

"Profanity is to treat other people unfairly. For me, it should be stopped to avoid complication." -NA

"Profanity is not good. All the people must avoid it to maintain peace in the society. I don't like using and hearing profanity because it discriminates people." - SP

"I think profanity makes the utterer very bad, and such profanity should not be uttered in the first place. I feel angry hearing profanity for it is not polite and makes anyone mad." - MX4

"Profanity touches my feelings and makes me angry. I feel like slapping the utterer because the use of profanity reflects one's language." - MX6

"Profanity should not be tolerated because it is bad. It should not be tolerated at any cost." -YJ

"Profanity should be stopped to maintain peacefulness in the community." -RJA

"Profanity is one of the worst things that have ever been created. It can hurt people around you emotionally." - RA

The preceding sample views from Islamic believers also depict profanity as not good, abuse, causing disharmony, irascibility, discrimination, discomfort, unhappiness, and emotional pain. Capping this prelude, one 
informant further commented that profanity reflects the personality of the utterer as stated by the informant ATBA quoted as follows:

"Profanity reflects the bad personality and impoliteness of the speaker. Moral and courteous people do not use profanity with ease. It makes me angry hearing profanity because it has bad elements that can influence negatively other people."

\section{Profanity in Cebuano}

Just like other Asian people, the Filipinos believe in the value of social cohesiveness with full consciousness of saving face. Among the Filipinos, the Cebuanos are mostly and primarily Catholic Christians. They are who the Philippines were because the Spanish conquistador Miguel Lopez de Legazpi set up the first colonial government in Cebu and subjugated the other natives from that place (Francia, 2010; Tan, 2009; Agoncillo, 1990). Along with the establishment of the colonial government, the Catholic Church by the patrons to real 'royal patronage' granted by Pope Julius II built churches, chapels, convents, and other religious edifices to impose complete control of the natives (Boruchoff, 2003; Aguilos, 1999).

With the introduction of a new religion, a new set of lexical items along with its conceptual structures was incorporated into the language of the Cebuanos thereby affecting and expanding their worldview. Aside from the religious register, many of the Spanish loanwords are those of flora and fauna which were brought to the Philippines from Mexico and the rest of the Spanish colonial world. By indoctrination and consequential conversion, the Cebuanos acquired novel and mysterious religious terms and concepts belonging to the Catholic Church.

\section{Spanish-based profanities in Cebuano}

Along with the religious terms also came profanities creeping into the native Cebuano tongue which became a marker of Hispanicization of the natives. Such profanities thrive to this day which is reminiscent of the $16^{\text {th }}$ to the $19^{\text {th }}$ century Spanish language. Samples of these Spanish-based profanities can be seen in Table 1. Table 1 shows the samples of Spanish-based ejaculatory profanities in Cebuano which are either religious or secular by nature. Structurally, such profanities are composed of either words or phrases. Of the 36 samples, 21 words are secular, and 15 words are religious by nature. Of these 21 secular words, only one refers directly to effluvia: caramba; two refer to illness: colera and peste; three refer directly to sex: cabron, carajo, and 
puñeta; five are pejorative: bastardo/bastarda, hijo de puta, muchacho/muchacha, peste, puta; and ten refer to unpleasant behavior: animal, bastos, estupido/estupida, gago/gaga, impertinente, inutil, Que barbaridad, Que horror, salvajes, and tonto/tonta.

Table 1. Spanish-Based Cebuano Profanities

\begin{tabular}{|c|c|c|}
\hline Number & Spanish-Based Profanities & Gloss \\
\hline 1 & Animal! & Animal! \\
\hline 2 & Ay San Pedro! & Oh Saint Peter! \\
\hline 3 & Ay Señor! & Oh Lord! \\
\hline 4 & Bastardo/bastarda! & Bastard! \\
\hline 5 & Bastos! & Rude, impolite \\
\hline 6 & Cabron! & Bastard, son of a bitch \\
\hline 7 & Caramba! & Good gracious! \\
\hline 8 & Carajo! & Dick! \\
\hline 9 & Colera! & Cholera \\
\hline 10 & Coño! & Cunt! Fuck! \\
\hline 11 & Demonio/Demonia! & Demon \\
\hline 12 & Dios mio! & My God! \\
\hline 13 & Estupido/Estupida! & Stupid \\
\hline 14 & Gago/gaga! & Crazy \\
\hline 15 & Hijo de Puta! & Son of a whore \\
\hline 16 & Impertinente! & Impertinent \\
\hline 17 & Inutil! & Useless, imbecile \\
\hline 18 & Madre de Dios! & Mother of God! \\
\hline 19 & Madre de Puta! & Mother of a whore! \\
\hline 20 & Madre mia! & My mother! \\
\hline 21 & Maldito/Maldita! & Damn! \\
\hline 22 & Moros! & Moors \\
\hline 23 & Muchacho/muchacha! & Young boy/young girl \\
\hline 24 & O Jesu-Cristo! & Oh, Jesus Christ! \\
\hline 25 & Peste! & Pestilence \\
\hline 26 & Por Dios! Por Santo! & For God's sake! \\
\hline 27 & Puñeta! & Masturbation \\
\hline 28 & Puta! & Whore \\
\hline 29 & Que barbaridad! & How awful! Outrageous! \\
\hline 30 & Que horror! & How horrible! \\
\hline 31 & Salvajes! & Savages \\
\hline 32 & Santa Maria! & Oh, Virgin Mary! \\
\hline 33 & Santissima (Trinidad)! & Oh most blessed (Trinity)! \\
\hline 34 & Satanas! & Satan! \\
\hline 35 & Susmaryosep! & Jesus, Mary, and Joseph! \\
\hline 36 & Tonto/Tonta! & Dumb! Stupid! \\
\hline
\end{tabular}


On the other hand, the 15 religion-based profanities include $A y$ San Pedro, Ay Señor, demonio/demonia, Dios mio, Susmaryosep, Madre de Dios, Madre de Puta, Madre mia, maldito/maldita, Moros, O Jesu-Cristo, Por Dios por Santo, Santissima (Trinidad), Satanas, Susmaryosep, and Santa Maria. Most of these religious profanities refer to the prominent figures in Roman Catholic theology both holy and unholy. Take for example the interjections $\boldsymbol{O}$ Jesu-Cristo, Santa Maria, Ay San Pedro, Ay Señor, and Santissima. These are direct references to Jesus Christ, the Blessed Virgin Mary, Saint Peter, the Lord God, and the Holy Trinity, respectively. In the case of the use of the names of the saints, the sample San Pedro is just the start of all the litanies of saints and angels such as those recited in the rosary, the string of beads used in Catholic communal prayers. All these expressions are a referent to everything holy and extremely sacrosanct core in the religiously charged mind of a devoted and pious Catholic, and that using these words in profanity raises the degree of validity and factuality of the context to which these expressions are appended and interpolated.

Conversely, the expressions demonio/demonia 'demon', Satanas 'Satan', and Moros 'Moors' are the opposite of what is considered holy and sacrosanct, thus expressing all the undesirable and unnamable horror and blasphemy which negate the entire context to which such expressions are appended and interpolated. It is worthy to note that the word Moros 'Moors' is used by the older generation to refer to anyone considered ill-educated, rude, and vulgar. For the older generation, being a Christian is equated with godliness, and being Moros or Muslims is otherwise. Nowadays, the younger generation used the pejorative word Muklu to mean the same. This perceived hatred and animosity had historical precedence when the Christian Cebuano communities were subjected by the Moros to periodical attack and pillage for the purpose of enforcing religious conversion, capturing Christian slaves, and commandeering properties (Agoncillo, 1990). This historical accident is not exclusive to the Christian communities, for the same horrors were inflicted upon the various Muslim communities by the most superior forces of the Spaniards who were aided by the Christian tribes (Majul, 1999). The Moros called the Christians kapil which is a phonologically adjusted word borrowed from the Arabic kafir 'infidel'. Mutual distrust exists and pejorative labelling continues between these two communities to this day.

\section{Indigenous Cebuano profanity}

Aside from the Spanish-based profanities discussed in section 3.1, other forms of profanities in Cebuano languages such as swearing and cursing are more on 
sentential forms. As expected, such forms of profanities include religious terms, but other forms have words of topographical elements, weather, flora, and fauna as seen below in Table 2.

Table 2. Cebuano Swearing and Cursing

\begin{tabular}{|c|c|c|}
\hline Number & Indigenous Cebuano Profanities & Gloss \\
\hline 1 & $\begin{array}{l}\text { Kung makasulti pa lang kining dakung } \\
\text { bato, mao ni musulti sa iyang bakak. }\end{array}$ & $\begin{array}{l}\text { 'If only this rock could speak, it would } \\
\text { tell his lies." }\end{array}$ \\
\hline 2 & Didto sa sapa niya gipamakak kana. & 'He denied it in the river.' \\
\hline 3 & $\begin{array}{l}\text { Ilalum ani jud nga kahuy iyang } \\
\text { gibungat kadtong mga pulunga. }\end{array}$ & $\begin{array}{l}\text { 'Under this very tree, he said those } \\
\text { words.' }\end{array}$ \\
\hline 4 & Nah, duul sa kalachuchi siya mibungat. & 'She said those words near the plumeria.' \\
\hline 5 & $\begin{array}{l}\text { Naay itom nga iring sa iyang tapad } \\
\text { mismo nakadungug sa iyang gisulti. }\end{array}$ & $\begin{array}{l}\text { 'There was a black cat beside him, and it } \\
\text { heard what he said.' }\end{array}$ \\
\hline 6 & $\begin{array}{l}\text { Gadaku ra imong lawas murag kabaw } \\
\text { apan wa kay buut! }\end{array}$ & $\begin{array}{l}\text { 'You are as big as a buffalo, but } \\
\text { senseless.' }\end{array}$ \\
\hline 7 & Irumbuang kang daku. & 'You are a rabid crazy dog.' \\
\hline 8 & $\begin{array}{l}\text { Saksi nako ang Ginoo nga tinuud } \\
\text { akong gisulti. }\end{array}$ & $\begin{array}{l}\text { 'God is my witness that I am telling the } \\
\text { truth.' }\end{array}$ \\
\hline 9 & $\begin{array}{l}\text { Didto mismo sa sulod sa simbahan } \\
\text { iyang gisulti. }\end{array}$ & 'He said those words inside the church.' \\
\hline 10 & $\begin{array}{l}\text { Gipanumpa ko ibabaw sa lubnganan sa } \\
\text { akong amahan/inahan. }\end{array}$ & $\begin{array}{l}\text { 'I swear on the grave of my } \\
\text { father/mother.' }\end{array}$ \\
\hline 11 & Lipakan ka unta! & 'May you be hit by lightning!' \\
\hline 12 & Anurun ka unta sa baha! & 'May you be carried away by the flood!' \\
\hline
\end{tabular}

As seen in Table 2, indigenous profanities are all in pure Cebuano words and are sentential in structure. It is in stark contrast to the examples presented in Table 1 where Spanish-based profanities are either single words or in phrases structurally. It is understandable since those profanities entered into the Cebuano language in the single lexical item or phrase forms. In Table 2, entries (1) and (2) mention the word bato 'rock' and sapa 'river' to prove of the purported lie and denial, respectively. Entries (3) and (4) use the words kahuy 'tree', and kalachuchi 'plumeria' in swearing and these are invoked as silent witnesses to prove the truth or to intensify stated facts. In entries (5) - (7), the sentential forms of swearing have the words itum nga iring 'black cat' which is bad luck, kabaw 'buffalo', and irumbuang 'rabid crazy dog' to prove the truth and to shame and to attack the dignity of the other person as part of emphasizing or supporting the purported truth or lie. Entries (8) - (10), have religious elements as indicated in the use of the words Ginoo 'God', simbahan 'church', and lubnganan 'grave' which are all incorporated due to its very high level of sanctity in swearing to prove the truth of utterances. Entries (11) and 
(12) make use of weather elements lipak 'lightning' and baha 'flood' to curse someone implying of deserved death of the person because of his perceived lies.

Other forms of indigenous Cebuano profanities are categorised under illness, sex, effluvia, and assault to the "face" like in the expressions listed in Table 3 below.

Table 3. Other Forms of Indigenous Cebuano Profanities

\begin{tabular}{|c|c|c|}
\hline Number & $\begin{array}{c}\text { Indigenous Cebuano } \\
\text { Profanities }\end{array}$ & Gloss \\
\hline 1 & Bwisit & 'damn, bullshit, jinx' \\
\hline 2 & Inatay & 'plague, sickness' \\
\hline 3 & Hinampak & 'plagued, cursed' \\
\hline 4 & Piskat & 'pink eye' \\
\hline 5 & Bahu kag ilok! & 'Your armpit stinks' \\
\hline 6 & Bahu kag lubut! & 'Your butt stinks' \\
\hline 7 & Bahu kag baba! & 'Your mouth stinks' \\
\hline 8 & Bahu kag bilat! & 'Your vagina stinks' \\
\hline 9 & Itum kag tai. & 'You got black feces' \\
\hline 10 & La kag ihi. & 'You got poisonous pee' \\
\hline 11 & La kag laway, murag bitin. & 'You got poisonous saliva like a snake' \\
\hline 12 & Utut nimo. & 'Your fart' \\
\hline 13 & Daku kag bilat! & 'Your vagina is big' \\
\hline 14 & Daku kag bugan! & 'Your crotch is big' \\
\hline 15 & Daku kag itlog! & 'Your testicles are big' \\
\hline 16 & Bilat sa iyang ina! & 'Your mother's cunt' \\
\hline 17 & Puki/Bilat nimo! & 'Your vagina!' \\
\hline 18 & Tinggil nimo! & 'Your clit!' \\
\hline 19 & Iyut! & 'Fuck!' \\
\hline 20 & Lulu nimo! & 'Masturbate yourself' \\
\hline 21 & Lusu nimo! & 'Your dick' \\
\hline 22 & Siga kag mata! & 'You got bulging eyes' \\
\hline 23 & Daku kag ilung! & 'You got big nose' \\
\hline 24 & Daku kag nawng! & 'You got big face' \\
\hline 25 & Baga kag nawng! & 'You got thick face' \\
\hline 26 & Yaya imong nawng! & 'You got a stupid sagging face! \\
\hline 27 & Nawng nimo ay, tanga ka! & 'Your face, stupid!' \\
\hline 28 & Danghag imong nawng! & 'Stupid face.' \\
\hline 29 & Wa kay kasingkasing. & 'You have no heart' \\
\hline 30 & Itum kag kasingkasing & 'You got black heart' \\
\hline 31 & Wa kay atay & 'You got no liver' \\
\hline 32 & Baga kag atay & 'You got thick liver' \\
\hline
\end{tabular}


In Table 3, entries (1) - (4) are the most frequently used single word vulgarities in Cebuano. The word bwisit is the most commonly heard vulgar word uttered when one is angry, annoyed, or frustrated. Nowadays, young people substitute bwisit with the English 'bullshit'. The word inatay refers to the plague or sickness 'atay' especially with the wholesale sudden death of chickens and other fowls in the farm in one season. Hinampak is derived from the base hampak which means 'curse' or 'plague', and subsumes all forms of punishment from any deity or God as if someone is cursed or suffered from plague, which is all deemed as acts of God. Entry number (4) piskat 'pink eye' refers to conjunctivitis as a curse to the interactant and the disgusting yellowish mucopurulent discharge from the infected eyes. Together with entry (4), the entries (5) - (7) are all about effluvia as shown by the word bahu 'stink' and the associated body parts like iluk 'armpit', baba 'mouth', lubut 'butt', and bilat 'vagina' from which the bahu 'stink' emanates. Similarly, entries (9) - (12) are also about effluvia as shown in words tai 'feces', ihi 'pee', laway 'saliva', and utut 'fart'. Entries (13) - (21) are all sexual profanities as shown in the words bilat/puki 'vagina', bugan 'crotch', itlog 'testicles', lusu 'penis', and lulu 'masturbation'. Entries (22) - (28) are all terms used in a direct assault to a person's face and appearance as shown in words mata 'eyes', ilung 'nose', and nawng 'face'. The used adjectives daku 'big', baga 'thick' and 'siga' 'bulging' are unpleasant when what is considered beautiful among the Cebuanos are the converse equivalence of these negative adjectives. Such converse equivalences are embodied by the Hispanic Cebuanos known as mestizos, the prototype of the Cebuano concept of beauty in contrast to the perceived indigenous ugliness. Furthermore, what is cynically hurting are the almost naturally collocating words such as danghag, yaya, and tanga which are glossed 'stupid' or more towards unfortunate natural stupidity. The last entries (29) - (32) have the anatomical words kasingkasing 'heart' and atay 'liver'. For Filipinos, the seat of emotions is the kasingkasing 'heart' to which all emotional appeals are addressed. And also just like the conceptualised liver among the Malay and Indonesian cousins of the Filipinos, in Cebuano atay 'liver' is also considered as a "symbol of the corresponding ethnopsychological construct" (Goddard, 2008:88). The negation of the existence and the disease of these anatomical parts are considered as an assault to the well-being and dignity of the person concerned. 


\section{Profanity in Bahasa Sug}

Discussing Tausug cannot be completely accomplished without touching the religion of Islam, which is the strongest identity marker of the Tausug community. Historical accounts celebrate the early unified political consciousness and religious identity of the Tausug when in 1450 the Sultanate of Sulu was declared a Darul Islam 'abode of peace' (Tan, 2010; Majul, 1999). The Islamized Tausugs were admitted to the universal concept of the ummat alIslamiyah 'the Islamic community'.

Compared to the preceding account of profanity among Christian Cebuanos, profanity among the Muslim Tausugs pales in comparison. Informants were quick to offer a reason saying that "profanity is considered haram 'forbidden' in Islam" and forms part of the major sins (as compared to the concept of venial sin among Christians). Islam, for Muslims, is not just simply a religion but also "a way of life" (Houben, 2003: 149). Albeit, the explicit expression of profanities exists in Tausug society, and Arabic religious terms are incorporated into the indigenous Bahasa Sug. Following sections present the samples of profanity in Bahasa Sug.

\section{Swearing in Bahasa Sug}

The Tausugs make use of words dealing with death and life endangerment when making a statement to prove the veracity of their utterance as shown in the following examples.

1. Bunnal ba. Matay pa aku bihaun. 'That is true. I may die now.'

2. Way aku nagdadagang shabu. Bunnal ba. Matay pa aku bihaun. 'I am not selling methamphetamine. It is true. I may die now.'

3. Kita ku in anak niya budjang ha tabuh nagmimiting iban sin anak subul hi Bapa Kadil. Bunnal ba. Matay pa aku bihaun. 'I saw his daughter in the market talking to the son of Uncle Kadil. That is true. I may die now.'

Sentences (1), (2), and (3) exemplify the common phrases of swearing among the Tausugs. To convince that they are telling the truth, Tausugs say, "Matay pa aku bihaun" 'I may die now'. Sample sentence (2) talks of the denial of selling methamphetamine, which is punishable by capital punishment in the Philippines, and the use of which is considered haram. Sample sentence (3) speaks of stealthy communication between unrelated man and woman seen in public, which is forbidden in the Tausug community. In these instances, 
informants asserted that the inclusion of the expression has a big impact on the part of the interactants because of the word "matay" 'death'.

Swearing as an oath is also expressed by direct mention of God and the angels to support the veracity of the utterance. Consider the samples (4), (5), and (6) below.

4. Way ku siya siyum. Saksih ku in Allah. Wallahi! 'I did not kiss her. God is my witness. I swear to Allah.'

5. Miyatay na hi Jared. Bukun ku puting. La ilaha illallah! 'Jared is dead. I am not lying. There is no God but Allah.'

6. Saksi ku in mga malaikat. Way ku nahinang yan. 'Angels are my witness. I have not done that.'

Sample sentence (4) mentions the word Allah, which the Arabic word for God, followed by the Arabic word Wallahi, which means 'I swear to God' in English. Sample sentence (5) talks about the death of a friend named Jared. To prove its factuality, part of the Arabic prayer Al Fatihah - La ilaha illallah 'There is no God but Allah'- is uttered to seal the finality of the truth of the sworn oath. Sample sentence (6) depicts a denial of an action, and to prove the veracity, the Arabic word malaikat 'angel' is evoked. These Arabic terms and expressions are commonly used among the Tausug informants to highlight the truth of the matter and to persuade the other interactants to the side of the speaker. To swear an oath among Muslims has both benefactive and malefactive effects "in this world and the hereafter" (Mohd Ab Malek bin Md Shah, et, al. 2013: 74).

\section{Cursing in Bahasa Sug}

Cursing in Bahasa Sug involves expressions of sickness, destruction, and death and often invoked to curse someone because of unpaid debts, saving face, and spreading lies. The following samples of cursing (7) - (10) are commonly used among the Tausug, and evoke death to the cursed person.

7. Nasalak kaw. 'May you die.'

8. Miyatay kaw. 'May you die.'

9. Nabugtang kaw. 'May you die.'

10. Nalaglag kaw. 'May you die.' 
The preceding samples of curses are also appended to utterances when someone collects payment of debt, and the debtor is known for habitual nonpayment or late payment of loans. Consider the sample statement below.

11. Kuhnu kaw magbayad sin utang mo? Nalaglag kaw. 'When will you pay your debt? May you die.'

In Tausug society, having debts is normal, but if it will not be paid, an altercation ensues more often than not. With the element of irascibility, the Tausug speaker utters this line out of anger and disappointment. He curses the delinquent debtor by saying, "Nalaglag kaw", to call the attention of the debtor to pay with the sense of necessity and urgency. One does not wish to die early, so the speaker is expecting that the debtor to pay as soon as possible.

Other instances of cursing in Tausug have something to do with telling lies, spreading slander, and committing impropriety. To these statements, curses shown in (7) - (10) are also appended as shown in samples (12), (13), (14), and (15) as follows.

12. Putingan in babuy ini. Syaytan tuud. Miyatay kaw. 'This pig is a liar. Truly, the devil. May you die.'

13. Ayaw nakaw pamuting! Nalka in kadtuan mu tuwan. Nalaglag kaw. 'Don't lie. You'll go to hell boy. May you die.'

14. Mayta mu siya siyum? Tunang sayan sin taymanghud mu. Nabugtang kaw. 'Why did you kiss her? She is the fiancée of your brother. May you die.'

15. Ig na kaw ha bay. Baisan kaw. Nasalak kaw. 'Get out from our house. You are a slut. May you die.'

In sample (2), the Tausug speaker utters this curse to the lying person who is then compared to a babuy 'pig'. Pig, labelled haram in Islamic jurisprudence, is the lowest form of an animal considered by Muslim Tausugs. The liar is then called Syaytan, Arabic for the devil, because of his act. The speaker here is usually confrontational and angry in uttering these lines. Sample (13) has the Arabic loanword nalka 'hell' which denotes the ultimate punishment for the lying person, a sharp disciplinary reprimand. Sample (14) states of a situation where the curse is uttered to the supposed offender accused of impropriety known in Islam as khalwat, an Arabic word which signifies forbidden proximity between unrelated members of opposite sex. As such, this act brings disgrace and causes shame to the family. Such gravity of offence to religion and culture demands a severe punishment, hence, the 
equally forceful curse Nabugtang kaw! 'May you die.' Sample (15) has the same value as that of the sample (14) wherein an offending daughter accused of impropriety and prostitution is driven out of the house. Prostitution is immoral in Islam and is categorized as haram. The samples (14) and (15) signify the strong following of the Tausugs of the adat 'customary laws' and the agama 'religion'. The Tausugs have the concept of addat 'customary laws' that is strongly enforced by the imam 'religious leader' and the taumaas 'elders' and generally observed by the Muslim community. The compelling strength and the binding power of addat are so robustly monumental that it is often said that a child can be left to die or even sacrificed just to preserve the addat.

\section{Other profanities in Bahasa Sug}

Sex, animal references, and weather elements also form part of profanities in Bahasa Sug. Consider the succeeding examples (16) - (21) as follows:

16. Jiyubul kaw! 'You are sodomised.'

17. Nag-iyut kay apu niya! 'She had sex with her grandfather.'

18. Nagkangug kaw! "You are fucking.'

19. Naglalasi na isab in bata-bata ini. Lisuan tuud! 'This boy is masturbating. You are indeed lazy.'

20. Nagdawgdug, nagkilat, nagkussu sin mata bilat! 'There is thunder; there is lightning; she poked her vagina.'

21. Nagdawgdug, nagluti, nagkussu sin mata buli! 'There is thunder; there is lightning; she poked her anus.'

The preceding samples of profanities have the element of sex. Sample (16) is an ejaculatory expression of profanity uttered when someone is angry or shocked like a startle response. The word jiyubul 'sodomized; is verb derived from the noun jubul 'anus'. Sample (17) makes use of the verb nag-iyut 'had sex' to denote the incestuous action done by the girl and her grandfather, which is also considered haram. This profanity is often mentioned for example when a Tausug does not win in the lottery. Having sex with a grandparent is considered a jinx, and such act is also punishable as well as the participation in the games of luck. Sample (18) has the verb nagkangug 'fucking', and sample (19) has the verb naglalasi 'masturbating'. Both are denoting sexual activities uttered in profanity. Informants were ardent in saying that such acts were not literally performed for it means that the person spoken to, such as the young child, is lazy and not doing anything, and therefore nothing prurient. Being habitually lazy may incur the label babuy 
' $p i g$ ', hated animal for being haram and characterised similarly for the habitual eating and sleeping of the pig.

Samples (20) and (21) are gathered from children playing who love to sing these lines when there are thunder and lightning. These particular samples are rhymes used in play among kids without any consciousness of impropriety, to the horror of the listening adults. In (20), the word bilat signifies the female genitalia being poked supposedly by the child herself when it is nagkilat 'lightning'. Similarly, sample (21) has the word buli 'anus' which also supposedly poked by the child when lightning strikes as depicted by the word nagluti 'lightning'. The listening adult usually sanctions the little ones by telling them that the lightning and thunder will not stop if they will not also stop playing and singing the profane rhyme. The fierce lightning and thunder may become more forceful and destructive due to the utterance of haram rhyme. To this end, the adult says the stern warning as seen below in (22):

22. Mga bata, mangi maglaka-laka. Kugdanan kamu sin kilat. 'Children, don't say those words. Lightning will strike you.'

This stern warning is often followed by the admonition of reciting Quran verses and prayers to stop the fearsome lightning and thunder. More often than not, this strict warning makes the playing kids stop, but not without the restrained playful giggling and chuckling.

\section{Conclusion}

The main focus of this ethnographic paper deals with the analysis of the expression of profanity in Cebuano and Bahasa Sug. This paper argues that the religions of Christianity and Islam play the role of the lexicalization of some profanities in the languages of Cebuano and Bahasa Sug, respectively. Such influence of lexicalized profanity is reflected in the incorporation of loanwords and religious terms coming from Spanish for Cebuano language and Arabic for Bahasa Sug. Religion plays a major role in the culture of the Cebuano and Tausug societies. In fact, it functions as an identity marker of the people, namely, Christianity for Cebuanos and Islam for the Tausugs.

For the Cebuanos, religious-based profanities include the employment of the concepts of Godhead in the form of Santissima Trinidad 'Holy Trinity', of the founder of Christianity, Jesus, in the expression Jesu-Cristo 'Jesus Christ', and of the Virgin Mary in the ejaculatory expression Santa Maria. Appended to 
the Christian God and the prominent heavenly figures are the angels and saints which were deeply ingrained in the religious consciousness of the Cebuanos. So deep that such terms are used without any premeditation, just a natural impulse like in a startle response. Other forms of Cebuano profanities are those that refer to sex and effluvia. The blunt explicitness of these profanities lies in the fact that the human genitalia, sexual acts, and sensual indecencies are mostly referred to in indigenous Cebuano language, wherein the vernacular expression evokes outright familiarity and severity of the associated act or performativity.

The level of vulgarity is heightened further in dealing with the profanity of effluvia which included indigenous expression of genitalia stink like in the expression bahu ug bilat 'stinky vagina' and body odour in bahu ug iluk 'smelly armpit' for example. Hurling insults, heaving invectives, and tossing expletives in the indigenous Cebuano are another aspect of Cebuano profanity that directs at the 'face' of the interactant. The section on Cebuano profanity has shown numerous examples enough to show the proliferation, casualness, and flagrance of the usage thereof. One of the reasons offered by the Cebuano informants as to why the multifarious expressions and the casualness of usage of profanity in Cebuano are that Christianity as a religion is a private matter and that uttering profanity is a venial sin and not mortal at all. Another reason invoked is that of freedom of expression. Another reason is that burst of emotion such as anger and excitement cannot be predicted nor controlled. These reasons give leverage and license for the use of profanity.

Profanity in Bahasa Sug includes the use of Arabic-based religious terms denoting the Godhead Allah 'God', the main adversary of goodness Syaytan 'devil', and the ministerial malaikat 'angel' in swearing and cursing. Such religious-based profanities expand in the direct use of swearing in Arabic like the expression Wallahi 'I swear to Allah' to prove the innocence of the speaker and the veracity of utterance, and the invocation of the last verse of the first chapter of the Quran Al Fatiha La ilaha illallah! 'There is no God but Allah' in sealing the finality of truth in the utterance. Such blasphemy of profanity is uttered under the grace of or the penalty of benefactive or malefactive effects in the present life and in the hereafter. In Islam, the malefactive effect in the hereafter means the soul is damned in nalka, which is an Arabic loanword meaning 'hell'.

Other forms of profanity in Bahasa Sug involve the use of references to death and destruction like in the sentential profanity Miyatay kaw 'May you $d i e^{\prime}$ and its alternates. These references are tied to the concept of what is religiously forbidden and sanctioned as embodied in the Islamic 
jurisprudential tenet of haram. Not paying debt is haram; prostitution is haram; lying to fellow Muslim is haram; eating pork and touching the pig is also haram. Added to this list of haram is khalwat 'proximity'. The penalty of committing haram is so severe, and that profanity with equated harshness and element of irascibility is hurled against the supposed culprit is deemed socially sanctioned, commensurate with the gravity of the offence, and entirely appropriate. This severe reaction goes with the idea of adat 'customary laws'. The Islamic Tausug society does not follow exclusively the Quran and the Sunnah 'Tradition'. The adat is also highly binding and commands communal observance in the Tausug society. This culturally ingrained customary law which predates Islam is upheld and elevated to the highest level of importance that gives birth to the concept of killing one's own child than to abandon or disobey the adat. In the words of one of the informants, he said, "Awn adat namu iban bar-iman kami mga Tausug." 'We follow the customary laws, and we are faithful to our religion.'

The Cebuanos and the Tausugs although separated by language and religion are all the same Filipino Austronesians. The natural setting that surrounds them and the meteorological elements that provide them similar weather experiences have made them use the words kilat 'lightning' and dawgdug 'thunder' in profanity. Flora and fauna and other topographical elements are also used in profanities wherein the presence of which in the particular location of utterance can add to the level of veracity. Both societies also consider that profanity is bad which gives emphasis to the similarity of accepted moral concepts of the two groups. This article has shown that profanity does not include only sex, religion, and effluvia as many studies have found. This paper has also argued that profanity can be in the form of assault to the "face", a very important psychosocial concept in the Cebuano and Tausug communities.

\section{References}

Adamec, L. (2009). Historical Dictionary of Islam, $2^{\text {nd }}$ edition. Lanham: Scarecrow Press, Inc.

Allan, K. \& Burridge, K. (2006). Forbidden Words: Taboo and Censoring of Language. Cambridge: Cambridge University Press.

Aguilos, R. (1999). Church realities in the Philippines: 1900-1965. AHIg8. PDF File pages 203-213. File Retrieved November 1, 2013 from www.dialnet.unirioja.es/servlet/fichero_articulo? codigo=233617 
Agoncillo, T. (1990). History of the Filipino People. Manila: GP Press.

Asad, T., Brown, W., Butler, J., Mahmood, S. (2013). Is Critique Secular? Blasphemy, Injury, and Free Speech. New York: Fordham University Press.

Bibi, A., \& Tollet, A.I. (2013). Blasphemy: A Memoir: Sentenced to Death Over a Cup of Water. Chicago: Chicago Review Press.

Boruchoff, D. (2003). Isabel la católica, Queen of Castile: Critical Essays. New York: Palgrave Macmillan.

Brown, P \& Levinson, S. (1987). Some Universals in Language Use. Cambridge: Cambridge University Press.

Burridge, Keith Allan, Kate (2000). Euphemism \& dysphemism: language used as shield and weapon (1st Replica Books ed.). Bridgewater, N.J.: Replica Books.

Corsini, R. (2002). The Dictionary of Psychology. New York: BrunnerRoutledge.

Culpeper, J. (2011). Impoliteness: Using Language to Cause Offense. Cambridge: Cambridge University Press.

Euphemism. (2013). In Merriam-Webster.com. Retrieved October 27, 2013, from http://www.merriam-webster.com/dictionary/euphemism

Francia, L. (2010). History of the Philippines: From Indios Bravos to Filipinos. New York: Overlook Press.

Gildrie, R. (2004). The Profane, the Civil, and the Godly: The Reformation of Manners in Orthodox New England, 1679-1749. University Park: Penn State University Press.

Goddard, C. (2008). Contrastive Semantics and Cultural Psychology: English Heart vs Malay Hati. In Sharifian, Farzad, Dirven, Rene, Ning Yu, \& Niemeier, Susan (eds). (2008). Culture, Body, and Language: Conceptualizations of Body Organs across Cultures and Languages. The Hague: Mouton de Gruyter (pages 75-102).

Heins, M. (2001). Not in Front of the Children: "Indecency", Censorship, and the Innocence of Youth. New York: Hill and Wang.

Holder, R. (2008). A Dictionary of Euphemisms. Oxford: Oxford University Press.

Houben, V. (2003). Southeast Asia and Islam. Annals of the American Academy of Political and Social Science, Vol. 588, Islam: Enduring Myths and Changing Realities (July 2003), pp. 149-170.

Jay, T. (2000). Why We Curse: A Neuro-Psycho-Social Theory of Speech. Philadelphia: John Benjamins Publishing Company. 
Jennings, B. (2009). Censorship: The Threat to Silence Talk Radio. New York: Threshold Editions.

Kamlian, J. (2005). Incidences of Clan Conflict and Conflict Management: Survey of Feuding Families and Clans in Selected Provinces of Mindanao. Washington, DC: Asia Foundation. Accessed December 28, 2013, http://asiafoundation.org/resources/pdfs/MSUIITExecSummary4.pdf

Kreuzer, P. (2005). Political Clans and Violence in Southern Philippines. Frankfurt: Peace Research Institute Frankfurt. Accessed on December 28, 2013, http://www.hsfk.de/downloads/PRIF-71.pdf

Majul, C. (1999). Muslims in the Philippines. Quezon City: University of the Philippines Press.

Mohd Ab Malek bin Md Shah, Sulaiman binMahzan, Siti Fairuz Nurr binti Sadikan, and Mohd Harun bin Shahudin. (2013). A Unique ReligioLegal Phenomenon of Oath: In the Purview of Jurisprudential Method of Islamic Law Evidence. In Proceeding - Kuala Lumpur International Business, Economics and Law Conference. April 8-9, 2013. Hotel Putra, Kuala Lumpur, Malaysia. ISBN 978-967-11350-1-3. Pages 74-86.

Mother Tongue-Based Multilingual Education. (2013). In www.deped.gov.ph. Accessed on October 28, 2013. http://www.deped.gov.ph/index.php/news-updates/updates/updateslearners/386-deped-adds-7-more-languages-in-mother-tongue-basededucation.

Murphy, C. (2013). God's Jury: The Inquisition and the Making of the Modern World. London: Penguin Group.

Part III. Life in Christ http://www.vatican.va/archive/ccc css/archive/catechism/p3s1c1a8.ht $\underline{\mathrm{m}}$

Roberts, K. \& Yamane, D. (2012). Religion in Sociological Perspective. London: Sage Publications.

Rodell, P. (2002). Culture and Customs of the Philippines. Westport: Greenwood Press.

Silverman, D. (2007). You Can't Air That: Four Cases of Controversy and Censorship in American Television Programming (Television and Popular Culture). New York: Syracuse University Press.

Tan, S. (2010). The Muslim South and Beyond. Quezon City: University of the Philippines Press.

Tan, S. (2009). A History of the Philippines. Quezon City: University of the Philippines Press. 
Torres, W. (ed.) (2007). "Rido: Clan Feuding and Conflict Management in Mindanao." Makati: The Asia Foundation.

Watts, R. (2003). Politeness: Key Topics in Sociolinguistics. Cambridge: Cambridge University Press. 